\title{
DAMPAK MOTIVASI KERJA, IKLIM ORGANISASI, LINGKUNGAN KERJA TERHADAP KEPUASAN KERJA KARYAWAN LEMBAGA PERKREDITAN DESA PECATU
}

\author{
Qisthio Wibiseno $^{1}$ \\ I Gusti Ayu Manuati Dewi ${ }^{2}$ \\ ${ }^{1,2}$ Fakultas Ekonomi dan Bisnis Universitas Udayana, Bali-Indonesia \\ e-mail: ts.kuliah@gmail.com
}

\begin{abstract}
ABSTRAK
Penelitian ini bertujuan untuk menguji pengaruh motivasi kerja, iklim organisasi, dan lingkungan kerja terhadap kepuasan kerja karyawan Lembaga Perkreditan Desa (LPD) Adat Pecatu. Penelitian ini menggunakan teknik pengambilan sampel jenuh dimana seluruh populasi yang berjumlah 49 orang digunakan sebagai sampel. indikator-indikator mengenai variabel penelitian yaitu motivasi kerja, iklim organisasi, lingkungan kerja, dan kepuasan kerja. Teknik analisis data yang digunakan adalah analisis regresi linier berganda. Hasil analisis menunjukkan bahwa motivasi kerja dan lingkungan kerja tidak memiliki pengaruh signifikan terhadap kepuasan kerja, akan tetapi variabel iklim organisasi terindikasi memiliki pengaruh positif signifikan terhadap kepuasan kerja.
\end{abstract}

Kata kunci: motivasi kerja, iklim organisasi, lingkungan kerja, kepuasan kerja

\section{ABSTRACT}

This research aims to determine the influence of work motivation, organizational climate, and work environment to job satisfaction of Lembaga Perkreditan Desa (LPD) Adat Pecatu employee. This research uses saturated sampling technique in which the entire population consisting of all 49 employees of LPD Adat Pecatu that used as research sample. Research data is collected using the questionnaire which contains the indicators of the research variable, consists of work motivation, organizational climate, work environment, and job satisfaction related questions. Data analysis technique used is multiple linear regression analysis. The results of the analysis showed that work motivation and work environment does not have significant influence towards job satisfaction, however, organizational climate have a positive and significant influence towards job satisfaction employee of LPD Adat Pecatu. Keywords: work motivation, organizational climate, work environment, job satisfaction 
Qisthio Wibiseno, Dampak Motivasi Kerja, Iklim Organisasi...

\section{PENDAHULUAN}

Desa Pakraman adalah sebuah bentuk organisasi sosial tradisional yang ada di Bali. Desa Pakraman memiliki hak otonom, salah satunya yaitu mengatur kegiatan sosial dan ekonomi serta mengelola kekayaan di lingkungan Desa Pakraman. Walaupun memiliki hak otonom, Desa Pakraman tetap saja harus mengikuti kebijakan pemerintah ataupun negara. Pemerintah daerah wajib membina Desa Pakraman untuk merancang sebuah kebijakan yang akan diterapkan di desa, salah satunya yaitu dengan menetapkan aturan tentang pendirian Lembaga Perkreditan Desa (LPD).

Lembaga Perkreditan Desa adalah adalah badan usaha milik desa yang melaksanakan kegiatan usaha di lingkungan desa untuk Desa Pakraman. Adapun tujuan pendirian LPD adalah untuk mendorong pembangunan ekonomi masyarakat desa melalui kegiatan penghimpunan tabungan dan deposito baik dari Krama Desa maupun penduduk luar desa, serta memberantas ijon, gadai gelap, menciptakan pemerataan kesempatan berusaha, dan perluasan kesempatan kerja bagi Krama Desa. Kegiatan operasional LPD tentunya membutuhkan tenaga karyawan untuk dapat berjalan dengan semestinya. Karyawan adalah mereka yang melakukan tugas dan tanggung jawabnya agar organisasi dapat mencapai tujuannya. Untuk mencapai tujuan tersebut, kondisi dari kepuasan kerja karyawan tentunya harus berada pada kondisi yang baik, sehingga mereka dapat bekerja secara optimal.

Kepuasan kerja adalah salah saktu faktor yang mempengaruhi bagaimana karyawan menjalankan tugas dan tanggungjawab dalam pekerjaan. Semakin puas seorang karyawan terhadap pekerjaannya, maka akan semakin baik pula kinerja dari 
karyawan tersebut. Maka dari itu, kepuasan kerja karyawan di sebuah organisasi harus terjaga pada tingkatan yang baik agar seluruh pekerjaan yang ada di organisasi dapat terselesaikan dengan baik. Menurut Afriani (2013), kepuasan kerja adalah hal utama yang harus diperhatikan oleh manajemen di sebuah organisasi karena pegawai yang puas terhadap pekerjaannya akan cenderung memberikan respon yang positif terhadap organisasi.

Zaman et al. (2014) menemukan bahwa motivasi kerja memiliki pengaruh positif dan signifikan terhadap kepuasan kerja, sehingga karyawan yang memiliki motivasi yang baik cenderung memiliki kepuasan kerja yang tinggi. Menurut Surachim (2008), iklim organisasi berpengaruh positif terhadap kepuasan kerja karyawan. Susanty (2012) menyatakan bahwa iklim organisasi di setiap organisasi berbeda antara satu dan yang lainnya. Perbedaan tersebut dapat mempengaruhi perilaku individu yang ada di organisasi tersebut. Anggota organisasi yang merasakan iklim organisasi yang baik akan merasa bahwa pekerjaan yang dilakukannya menyenangkan dan berharga.

\section{Tabel 1.}

Data Kepuasan Kerja Karyawan LPD Adat Pecatu - Hasil Pra-survei

\begin{tabular}{|c|c|c|c|c|c|c|}
\hline No. & Pertanyaan & STS & TS & $\mathbf{N}$ & $\mathbf{S}$ & SS \\
\hline 1 & $\begin{array}{l}\text { Saya merasa puas karena gaji yang diterima sesuai dengan } \\
\text { beban kerja saya. }\end{array}$ & - & 5 & 4 & 1 & - \\
\hline 2 & Saya merasa puas dengan pekerjaan yang saya miliki & - & 4 & 6 & - & - \\
\hline 3 & $\begin{array}{l}\text { Saya merasa puas karena adanya kesempatan untuk } \\
\text { mendapat promosi ke jabatan yang lebih tinggi }\end{array}$ & 1 & 2 & 4 & 3 & - \\
\hline 4 & $\begin{array}{l}\text { Saya merasa puas karena pengawasan yang diberikan atasan } \\
\text { sangat baik. }\end{array}$ & - & 2 & 5 & 3 & - \\
\hline 5 & $\begin{array}{l}\text { Saya merasa puas karena memiliki rekan kerja } \\
\text { yang mampu membuat situasi kerja menyenangkan. }\end{array}$ & - & 7 & 1 & 2 & - \\
\hline & Total & 1 & 20 & 20 & 9 & - \\
\hline
\end{tabular}

Sumber: Data primer diolah, 2018. 


$\begin{array}{lll}\text { Keterangan: } \text { STS }= & \text { Sangat tidak setuju. } \\ \text { TS } & = & \text { Tidak setuju. } \\ \text { N } & = & \text { Netral. } \\ \text { S } & = & \text { Setuju. } \\ \text { SS } & = & \text { Sangat setuju. }\end{array}$

Wibowo (2014) mengemukakan bahwa faktor lingkungan kerja fisik dan lingkungan kerja non fisik memiliki pengaruh yang positif dan signifikan terhadap kepuasan kerja karyawan. Data kepuasan kerja karyawan LPD Adat Pecatu yang dihimpun melalui penyebaran kuesioner pra-survei kepada 10 karyawan LPD Adat Pecatu dapat dilihat pada Tabel 1.

Data pada Tabel 1 mengindikasikan bahwa adanya kepuasan kerja karyawan yang rendah di LPD Adat Pecatu. Hal ini dapat dilihat dari jawaban yang lebih banyak berada pada posisi "tidak setuju". Kondisi ini mengindikasikan adanya masalah kepuasan kerja di LPD Adat Pecatu. Untuk itu perlu dilakukan penelitian mengenai faktor-faktor yang menjadi penyebab rendahnya kepuasan kerja karyawan di LPD ini.

Berlandaskan penelusuran terhadap hasil-hasil penelitian terdahulu, ketidakpuasan terhadap pekerjaan dapat dipengaruhi oleh beberapa variabel, diantaranya motivasi kerja, iklim organisasi, dan lingkungan kerja. Akan tetapi, hasil-hasil studi empiris tersebut menunjukkan hasil yang tidak konsisten. Ada yang menyatakan bahwa ketiga variabel tersebut berpengaruh signifikan dan ada pula yang menunjukkan bahwa motivasi kerja, iklim organisasi, dan lingkungan kerja tidak berpengaruh signifikan terhadap kepuasan kerja.

Penelitian Dhermawan et al. (2012) menyatakan bahwa variabel motivasi kerja dan lingkungan kerja tidak berpengaruh signifikan terhadap kepuasan kerja. 
Hal tersebut berarti bahwa sebaik apapun motivasi dan kondisi lingkungan kerja, tidak akan mempengaruhi tingkat kepuasan kerja karyawan. Tetapi, penelitian Sardzoska dan Tang (2012) dan Zaman et al. (2014) menemukan hal yang bertolak belakang dengan penelitian yang dilakukan Dhermawan. Hasil penelitian mereka menunjukkan bahwa lingkungan kerja yang baik akan menyebabkan tingginya kepuasan kerja karyawan. Pada hasil penelitian kedua kelompok peneliti tersebut, terindikasi bahwa motivasi kerja berpengaruh positif terhadap kepuasan kerja. Hasil tersebut menunjukkan bahwa semakin baik motivasi kerja dan kondisi lingkungan kerja, maka semakin puas pula karyawan terhadap pekerjaanya. Untuk penelitian tentang hubungan antara iklim organisasi dan kepuasan kerja, Susanty (2012) menemukan bahwa iklim organisasi tidak berpengaruh signifikan terhadap kepuasan kerja, sedangkan Sari (2011) menemukan hubungan positif dan signifikan antara kedua variabel tersebut. Berdasarkan dari acuan yang dijabarkan sebelumnya, terdapat kesenjangan dari hasil penelitian-penelitian terdahulu, sehingga fenomena ini perlu diselidiki lebih dalam dengan menguji hubungan dari variabel-variabel yang terkait.

\section{Teori Dua Faktor}

Teori dua faktor yang dikemukakan oleh Frederick Hezberg dijadikan acuan dalam penelitian ini. Dirujuk dari Aruan dan Fakhri (2017), teori ini menyatakan bahwa ada dua faktor yang dapat menyebabkan timbulnya rasa puas atau tidak puas terhadap suatu pekerjaan. Faktor-faktor tersebut adalah hygiene factor dan motivational factor. 
Qisthio Wibiseno, Dampak Motivasi Kerja, Iklim Organisasi...

Hygiene factor adalah hal yang mencakup status seseorang dalam organisasi seperti hubungan individu dengan atasan dan rekan kerjanya, teknik supervisi yang diterapkan oleh penyelia, kebijakan organisasi, sistem administrasi organisasi, kondisi kerja, dan sistem imbalan yang berlaku. Motivational factor adalah hal-hal yang dapat mendorong seseorang untuk berprestasi yang bersifat intrinsik, seperti pekerjaan, keberhasilan yang diraih, kesempatan bertumbuh, kemajuan dalam karir, dan pengakuan dari orang lain.

\section{Pengertian Motivasi Kerja}

Motivasi kerja adalah sebuah keinginan untuk melakukan suatu usaha untuk mengeluarkan sejumlah upaya dengan intensitas tinggi demi memenuhi tujuan organisasi (Robbins, 2002:55). Motivasi adalah salah satu proses yang kompleks dalam rangkaian aktivitas individu. Motivasi adalah aspek penting bagi individu, terlebih bagi seorang karyawan karena implikasi langsung dari motivasi kerja akan mempengaruhi kinerjanya. Gîlmeanu (2015) menyatakan bahwa motivasi dapat membawa individu kepada rasa puas atas pekerjaan yang telah dilakukan yang selanjutnya mengarahkan karyawan untuk menunjukkan kinerja yang baik.

Menurut Luthans (2006:147), proses motivasi kerja terdiri dari tiga elemen penting, yaitu kebutuhan (needs), dorongan (drives), dan rangsangan (incentives). Kebutuhan adalah tekanan yang timbul karena adanya kekurangan yang dirasakan individu, sehingga mereka terdorong untuk memenuhi kekurangan tersebut. Kekurangan yang dimaksud dapat bersifat psikologis, fisiologis, atau sosial. Dorongan adalah sebuah niat yang menyebabkan seseorang melakukan tindakan 
untuk mencapai kebutuhan. Rangsangan adalah sesuatu yang akan menimbulkan minat seseorang untuk berusaha mencapai tujuan.

\section{Pengertian Iklim Organisasi}

Iklim organisasi berhubungan dengan karakteristik lingkungan yang berpengaruh terhadap tingkah laku orang yang berada dalam organisasi serta segala sesuatu yang ada dalam organisasi seperti sistem formal dan gaya kepemimpinan. Faktor lingkungan dan faktor lainnya juga akan berpengaruh kepada sikap, kepercayaan, nilai, dan motivasi orang yang bekerja dalam organisasi tersebut (Setiawan, 2015). Iklim organisasi adalah atmosfir yang dominan di dalam sebuah organisasi meliputi persepsi terhadap organisasi, kerjasama, dan tingkatan kepercayaan dalam organisasi (Asif, 2011).

Menurut Rahimić (2013), iklim organisasi adalah suasana dalam organisasi yang dapat mendukung pelaksanaan tugas dan pekerjaan dengan tanggung jawab anggota organisasi, etika berorganisasi, kepedulian antara anggota organisasi dan kerjasama antar anggota organisasi. Iklim organisasi berbeda antara satu organisasi dengan yang lainnya. Perbedaan tersebut dapat mempengaruhi sikap dan perilaku individu yang ada di organisasi yang bersangkutan. Anggota organisasi yang merasakan iklim organisasi yang baik akan memandang pekerjaan yang dilakukannya menyenangkan dan berharga (Susanty, 2012). Stinger dalam Kustianto dan Iskhak (2015) mengartikan iklim organisasi sebagai koleksi dan pola lingkungan yang menyebabkan munculnya motivasi serta berfokus pada persepsi persepsi yang masuk akal, sehingga mempunyai pengaruh langsung terhadap kinerja anggota organisasi. 
Qisthio Wibiseno, Dampak Motivasi Kerja, Iklim Organisasi...

\section{Pengertian Lingkungan Kerja}

Lingkungan kerja yaitu suatu kondisi dimana karyawan melaksanakan dan menjalankan tugas dan pekerjaannya setiap harinya (Ahyari, 2005:124). Sementara menurut Subagyo (2014) lingkungan kerja adalah komponen-komponen dari dalam dan luar organisasi yang dapat mempengaruhi kinerja organisasi. Lingkungan kerja merupakan komponen yang dapat dikendalikan dan juga tidak dapat dikendalikan dalam keadaan tertentu.

Kondisi ruang kerja yang baik, bersih, nyaman, dan memenuhi standar kebutuhan pekerjaan akan menunjang efisiensi pekerjaan yang dilakukan oleh karyawan (Newsham, 2009). Kondisi lingkungan kerja yang baik dan sehat dalam

organisasi juga akan mendorong karyawan agar lebih termotivasi untuk mengerahkan segala kemampuannya dalam mengerjakan tugas yang diberikan serta tidak menyimpang dari tujuan atau misi awal perusahaan (Bakhtiar, 2012).

\section{Pengertian Kepuasan Kerja}

Brown et al. (2010) mengartikan bahwa kepuasan kerja sebagai tingkat kecintaan atas pekerjaan yang dimiliki. Kepuasan kerja adalah orientasi afektif seseorang terhadap pekerjaannya. Hal tersebut meliputi bagaimana perasaan individu terhadap pekerjaannya yang dapat dipengaruhi oleh berbagai aspek (Hoboubi et al., 2016).

Kepuasan kerja dapat dikatakan sebagai salah satu faktor utama dari efektivitas dan efisiensi dari organisasi bisnis. Ketika menganalisis kepuasan kerja, logika sederhana yang muncul adalah ketika karyawan merasa puas, karyawan akan 
merasa senang dan selanjutnya karyawan tersebut bisa dikatakan sebagai karyawan yang sukses (Aziri, 2011).

\section{Pengaruh Motivasi Kerja Terhadap Kepuasan Kerja}

Menurut Handoko dalam Mardiono (2015), motivasi kerja berpengaruh positif terhadap kepuasan kerja karyawan. Motivasi tersebut berdasar dari keinginan untuk mencukupi kebutuhan-kebutuhannya. Kebutuhan tersebut antara lain kebutuhan pangan, sandang, papan, kebutuhan akan rasa aman dalam bekerja, pengakuan atas pekerjaan, dan aktualisasi diri dalam lingkungan kerjanya. Kebutuhan-kebutuhan tersebut akan menciptakan kepuasan pada karyawan yang berhasil untuk memenuhinya.

Gîlmeanu (2015) menyatakan bahwa motivasi dapat membawa seseorang kepada rasa puas atas pekerjaan yang telah dilakukan. Penelitian yang dilakukan oleh Kartika dan Kaihatu (2012), Singh et al. (2011) dan Dewi dan Dewi (2015) menemukan bahwa motivasi kerja memiliki pengaruh positif signifikan terhadap kepuasan kerja karyawan. Sejalan dengan itu, hasil penelitian Zaman et al. (2014) juga menyatakan bahwa ada hubungan positif antara motivasi kerja dengan kepuasan kerja. Penelitian yang dilakukan oleh Maurya dan Agarwal (2018) juga menunjukkan hasil yang sama, bahwa semakin tinggi motivasi kerja, maka semakin tinggi pula kepuasan kerja yang ditunjukkan oleh karyawan. Pernyataan tersebut berarti bahwa motivasi kerja dapat meningkatkan kepuasan kerja dari setiap individu yang diteliti.

Motivasi kerja memiliki hubungan positif dan signifikan dengan kepuasan kerja baik untuk laki-laki maupun perempuan. Penelitian yang dilakukan Louise 
Qisthio Wibiseno, Dampak Motivasi Kerja, Iklim Organisasi...

dan Botha (2014) pada karyawan toko grosir di Pretoria, Afrika Selatan juga menunjukkan adanya hubungan positif antara kepuasan kerja dengan motivasi kerja. Hasil penelitian tersebut juga sejalan dengan penelitian Mardiono (2015) dan Brahmasari dan Suprayetno (2009) yang menyatakan bahwa motivasi kerja berpengaruh signifikan terhadap kepuasan kerja karyawan. Stringer et al. (2011) dalam penelitiannya menemukan bahwa motivasi intrinsik memiliki hubungan positif dengan kepuasan kerja, namun tidak dengan motivasi ekstrinsik. Dapat disimpulkan bahwa jika karyawan memiliki motivasi yang baik, maka kepuasan kerja karyawan akan menjadi baik pula, sehingga dapat dikatakan bahwa motivasi berpengaruh positif terhadap kepuasan kerja.

$\mathrm{H}_{1}$ : Motivasi kerja berpengaruh positif dan signifikan terhadap kepuasan kerja.

\section{Pengaruh Iklim Organisasi Terhadap Kepuasan Kerja}

Menurut Litwin dan Stringer dalam Susanty (2012), iklim organisasi memiliki dampak pada kepuasan dan motivasi kerja. Kepuasan kerja harus diciptakan sebaik mungkin agar moral kerja, dedikasi, kecintaan, dan disiplin yang dimiliki karyawan meningkat. Penelitian yang dilakukan Rahimić (2013) menemukan bahwa iklim organisasi memiliki pengaruh signifikan terhadap kepuasan kerja karyawan di perusahaan yang ada di Bosnia dan Herzegovina. Sari (2011) menyatakan bahwa iklim organisasi memiliki pengaruh positif yang kuat terhadap kepuasan kerja karyawan. Hasil penelitian ini sejalan dengan penelitian yang dilakukan oleh Thakre dan Shroff (2016) yang menunjukkan bahwa karyawan dengan iklim organisasi yang baik memiliki kepuasan kerja yang tinggi. 
Penelitian pada beberapa Bank Islam di Timur Tengah yang dilakukan oleh Khan et al. (2013) juga menunjukkan hasil yang sama, bahwa iklim organisasi berpengaruh positif dan signifikan terhadap kepuasan kerja karyawan yang menjadi responden. Kondisi ini mengindikasikan bahwa iklim organisasi yang baik akan meningkatkan kepuasan kerja karyawan. Kumar (2015) juga menemukan bahwa variabel iklim organisasi memiliki hubungan positif dengan kepuasan kerja pada sampel yang di teliti. Hasil penelitian tersebut juga sejalan dengan penelitian terbaru oleh Yani dan Wijaya (2016) yang juga menunjukkan bahwa iklim organisasi secara parsial berpengaruh signifikan terhadap kepuasan kerja. Berdasarkan hasil penelitian tersebut dapat dikatakan bahwa iklim organisasi yang baik menyebabkan peningkatan kepuasan kerja karyawan.

$\mathrm{H}_{2}$ : Iklim organisasi berpengaruh positif dan signifikan terhadap kepuasan kerja.

\section{Pengaruh Lingkungan Kerja Terhadap Kepuasan Kerja}

Lingkungan kerja adalah salah satu aspek terpenting dalam sebuah organisasi. Kondisi lingkungan kerja yang baik adalah hal yang diharapkan oleh setiap karyawan. Lingkungan kerja yang baik akan membuat karyawan bekerja dengan nyaman dan berujung pada pelaksanaan tugas yang efisien (Paramita et al., 2013). Sardzoska dan Tang (2012) dan Annakis et al. (2011) menyatakan bahwa lingkungan kerja yang baik memiliki hubungan dengan tingginya kepuasan kerja. Ashraf et al. (2013), serta Raziq dan Maulabakhsh (2015) juga menemukan hubungan positif dan signifikan antara variabel lingkungan kerja dan kepuasan kerja. Pernyataan tersebut berarti bahwa semakin baik kondisi lingkungan kerja, maka akan semakin puas pula karyawan terhadap pekerjaannya. 
Dalam penelitian Aruan dan Fakhri (2017) dan Wibowo (2014) faktor lingkungan kerja fisik dan lingkungan kerja non fisik terbukti memiliki pengaruh yang positif dan signifikan terhadap kepuasan kerja karyawan. Sejalan dengan penelitian tersebut, hasil riset Al-Hamdan et al. (2017) yang dilakukan pada lingkungan kerja perawat di Yordania juga menemukan hubungan positif dan signifikan antara lingkungan kerja para perawat dan kepuasan kerja mereka. Berdasarkan penelitian-penelitian tersebut, dapat disimpulkan bahwa semakin baik lingkungan kerja, maka semakin tinggi pula kepuasan kerja yang dirasakan oleh karyawan.

$\mathrm{H}_{3}$ :Lingkungan kerja berpengaruh positif dan signifikan terhadap kepuasan kerja.

\section{Kerangka Konseptual}

Berdasarkan penelusuran baik terhadap studi konseptual maupun teoritis, dapat disusun kerangka konseptual sebagaimana terlihat pada Gambar 1.

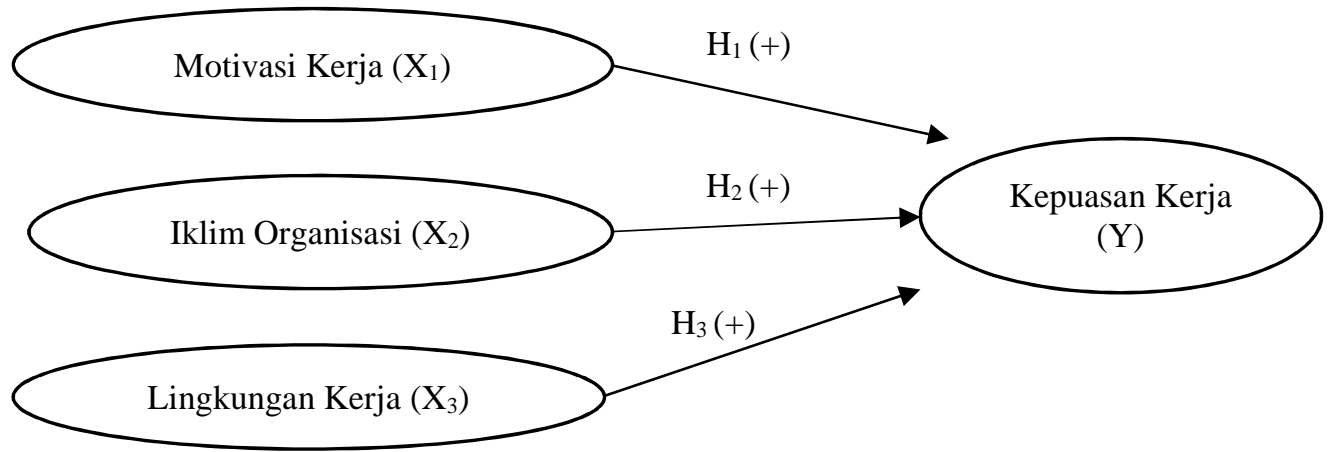

Gambar 1. Kerangka Konseptual Penelitian

\section{METODE PENELITIAN}

Penelitian ini dilaksanakan di LPD Adat Pecatu. Lokasi penelitian ini dipilih karena berdasarkan survei awal terdapat masalah pada kepuasan kerja karyawan. Untuk memperoleh data guna memenuhi kebutuhan penelitian, data primer 
dikumpulkan dengan cara menyebarkan kuesioner kepada responden penelitian. Kuesioner yang diberikan pada responden berupa daftar pertanyaan untuk menghimpun data motivasi kerja, iklim organisasi, lingkungan kerja, dan kepuasan kerja karyawan.

Populasi dalam penelitian ini adalah seluruh karyawan LPD Adat Pecatu kecuali pihak pimpinan dan pengurus yang terdiri dari Kepala LPD, bendahara, dan sekretaris. Karyawan yang diteliti adalah karyawan pada bagian akuntansi, bagian dana, bagian kredit, dan bagian umum yang seluruhnya berjumlah 49 orang.

\section{HASIL DAN PEMBAHASAN}

\section{Karakteristik Responden Secara Deskriptif}

Uraian tentang karakteristik responden secara deskriptif pada penelitian ini dibedakan berdasarkan jenis kelamin, usia, dan tingkat pendidikan. Tabel 2 menunjukkan karakterisik responden berdasarkan klasifikasi tersebut.

Tabel 2.

Distribusi Karakteristik Responden Menurut Jenis Kelamin, Usia, dan Tingkat Pendidikan

\begin{tabular}{ccc}
\hline Jenis Kelamin & Jumlah (orang) & Persentase (\%) \\
\hline Laki-laki & 29 & 59,18 \\
Perempuan & 20 & 40,82 \\
\hline Total & $\mathbf{4 9}$ & $\mathbf{1 0 0}$ \\
\hline Usia & 3 & 6.12 \\
30 tahun & 11 & 22,44 \\
$30-35$ tahun & 8 & 16,32 \\
$36-41$ tahun & 14 & 28,57 \\
$42-47$ tahun & 12 & 24,48 \\
$48-53$ tahun & 1 & 2,07 \\
$>$ 54 tahun & $\mathbf{4 9}$ & $\mathbf{1 0 0}$ \\
\hline Total & Jumlah & Persentase \\
Tingkat Pendidikan & 5 & 10,20 \\
SMP Sederajat & 16 & 32,65 \\
SMA Sederajat & 7 & 14,28 \\
Diploma & 21 & 42,87 \\
Strata 1 & $\mathbf{4 9}$ & $\mathbf{1 0 0}$ \\
\hline Total & &
\end{tabular}

Sumber: Data primer diolah, 2018. 
Qisthio Wibiseno, Dampak Motivasi Kerja, Iklim Organisasi...

Tabel 2 menunjukkan bahwa 59,18\% dari responden adalah karyawan yang berjenis kelamin laki-laki. Hal ini disebabkan oleh deskripsi pekerjaan seperti pengoperasian sarana komunikasi dan transportasi dalam kegiatan operasional LPD serta melaksanakan program promosi dan pemasaran produk-produk kredit kepada masyarakat yang membutuhkan tenaga karena dilakukan di lapangan sedangkan karyawan perempuan yang jumlahnya lebih sedikit ditempatkan pada bagian front desk untuk melayani nasabah.

Sebagian besar responden berada pada rentangan umur 30-53 tahun. Hanya sedikit yang berumur kurang dari 30 tahun $(6,12 \%)$ dan di atas 54 tahun $(2,04)$. Berdasarkan hasil wawancara dengan pihak pengurus LPD Adat Pecatu, hal ini disebabkan oleh kebutuhan LPD Adat Pecatu akan karyawan yang bekerja di lapangan dengan kisaran umur antara 42 - 47 tahun karena sudah memiliki pengalaman yang baik serta stamina yang cukup untuk melakukan pekerjaan operasional dan tugas lapangan serta dapat bekerja lebih efisien dibandingkan tenaga kerja yang berusia lanjut.

Responden mempunyai tingkat pendidikan yang beragam mulai dari Sekolah Menengah Pertama/Sederajat (SMP), Sekolah Menengah Atas/Sederajat (SMA), Diploma, hingga Strata 1. Responden yang berpendidikan Strata 1 berjumlah 42,85\%. Hal ini disebabkan oleh tuntutan pekerjaan yang mengharuskan karyawan mempunyai pendidikan yang memadai untuk melaksanakan tugas-tugas seperti menganalisis laporan keuangan, pembukuan, dan pekerjaan yang berhubungan dengan akuntansi. 


\section{Uji Normalitas}

Uji normalitas bertujuan untuk menguji apakah dalam residual dari model regresi yang dibuat berdistribusi normal ataukah tidak. Data yang berdistribusi normal memiliki nilai $\mathrm{p}>0,05$ atau tidak signifikan yang berarti distribusi data empirik bersifat normal. Berdasarkan pengolahan data yang telah dilakukan, didapat angka signifikansi 0,149. Angka signifikansi tersebut lebih besar dari taraf signifikansi $0,05(0,149>0,05)$ sehingga dapat disimpulkan bahwa data berdistribusi normal.

\section{Uji Multikolinieritas}

Uji multikolinieritas bertujuan untuk menguji apakah pada model regresi ditemukan adanya korelasi antar variabel bebas. Kriteria pengujian adalah jika nilai VIF pada hasil output pengolahan data SPSS adalah $<10$ maka tidak ada gejala multikolinieritas. Jika $V I F>10$, maka terjadi gejala multikolinieritas pada variabel bebas. hasil uji multikolinieritas dapat dilihat secara rinci pada Tabel 3.

\section{Tabel 3.}

Hasil Uji Multikolinieritas

\begin{tabular}{ccc}
\hline Variabel & Nilai $\boldsymbol{V I F}$ & Keterangan \\
\hline Motivasi kerja & 2,398 & $\begin{array}{l}\text { Tidak ada gejala } \\
\text { multikolinieritas }\end{array}$ \\
Iklim organisasi & 1,738 & $\begin{array}{l}\text { Tidak ada gejala } \\
\text { multikolinieritas }\end{array}$ \\
Lingkungan kerja & 1,974 & $\begin{array}{l}\text { Tidak ada gejala } \\
\text { multikolinieritas }\end{array}$ \\
\hline
\end{tabular}

Sumber: Data primer diolah, 2018.

Berdasarkan hasil pengolahan data, tidak ada gejala multikolinieritas di antara variabel bebas karena nilai VIF pada tiap variabel bebas adalah $<10$. 
Qisthio Wibiseno, Dampak Motivasi Kerja, Iklim Organisasi...

\section{Uji Heteroskedastisitas}

Uji heteroskedastisitas bertujuan untuk menguji apakah dalam model regresi terjadi ketidaksamaan varians dari residual satu pengamatan ke pengamatan lainnya. Model regresi yang baik adalah model yang tidak mengandung gejala heteroskedastisitas. Model regresi yang mengandung gejala heteroskedastisitas akan menyebabkan penyimpangan prediksi. Uji heteroskedastisitas pada penelitian ini menggunakan uji Glejser dengan hasil sebagai berikut pada Tabel 4.

Tabel 4.

Hasil Uji Heteroskedastisitas

\begin{tabular}{ccc}
\hline Variabel & Nilai Signifikansi & Keterangan \\
\hline Motivasi kerja & 0,594 & $\begin{array}{c}\text { Tidak ada gejala } \\
\text { heteroskedastisitas } \\
\text { Tidak ada gejala } \\
\text { heteroskedastisitas } \\
\text { Tidak ada gejala } \\
\text { heteroskedastisitas }\end{array}$ \\
\hline
\end{tabular}

Sumber: Data Primer diolah, 2018.

Berdasarkan uji heteroskedastisitas dengan uji Glejser, tampak bahwa angka signifikansi seluruh variabel bebas $>0,05$. Hal ini menandakan bahwa tidak ada gejala heteroskedastisitas dalam model regresi.

\section{Analisis Regresi Linier Berganda}

Analisis regresi linier berganda digunakan untuk mengetahui ada atau tidaknya pengaruh dari variabel bebas terhadap variabel terikat. Variabel bebas dalam penelitian ini antara lain yaitu motivasi kerja $\left(\mathrm{X}_{1}\right)$, iklim organisasi $\left(\mathrm{X}_{2}\right)$, dan lingkungan kerja $\left(\mathrm{X}_{3}\right)$ dengan variabel terikat kepuasan kerja $(\mathrm{Y})$. 
Tabel 5.

Hasil Analisis Regresi Linier Berganda

\begin{tabular}{|c|c|c|c|c|c|}
\hline \multirow[t]{2}{*}{ Variabel } & \multicolumn{2}{|c|}{$\begin{array}{c}\text { Unstandardized } \\
\text { Coefficients }\end{array}$} & \multirow{2}{*}{$\begin{array}{c}\text { Standardized } \\
\text { Coefficients } \\
\text { Beta } \\
\end{array}$} & \multirow[t]{2}{*}{$\mathbf{t}$} & \multirow[t]{2}{*}{ Sig. } \\
\hline & B & Std. Error & & & \\
\hline (Constant) & 1,368 & 2,949 & & 0,464 & 0,645 \\
\hline $\begin{array}{c}\text { Motivasi } \\
\text { kerja }\left(\mathrm{X}_{1}\right)\end{array}$ & $-0,024$ & 0,090 & $-0,044$ & $-0,265$ & 0,792 \\
\hline $\begin{array}{c}\text { Iklim } \\
\text { organisasi } \\
\left(\mathbf{X}_{2}\right)\end{array}$ & 0,501 & 0,118 & 0,600 & 4,249 & 0,000 \\
\hline $\begin{array}{l}\text { Lingkungan } \\
\text { kerja }\left(X_{3}\right)\end{array}$ & 0,172 & 0,129 & 0,201 & 1,338 & 0,188 \\
\hline $\mathbf{R}$ & 0,696 & & & & \\
\hline R Square & 0,484 & & & & \\
\hline F & 14,087 & & & & \\
\hline F Sig. & 0,000 & & & & \\
\hline
\end{tabular}

Hasil analisis regresi linier berganda secara rinci dapat dilihat pada Tabel 5.

Berdasarkan hasil analisis, dapat disusun persamaan regresi linier sebagai berikut.

$$
Y=1,368-0,024 X_{1}+0,501 X_{2}+0,172 X_{3}
$$

Persamaan regresi linier berganda tersebut secara rinci dapat diuraikan sebagai berikut.

1) Nilai $\beta \mathrm{X}_{1}$ sebesar $-0,024$ berarti bahwa motivasi kerja tidak berpengaruh signifikan terhadap kepuasan kerja karyawan LPD Adat Pecatu karena nilai p lebih besar dari 0,05 (0,792). Jika motivasi kerja meningkat, tidak akan terjadi peningkatan kepuasan kerja.

2) Nilai $\beta X_{2}$ sebesar 0,501 berarti bahwa iklim organisasi berpengaruh positif terhadap kepuasan kerja karyawan LPD Adat Pecatu. Jika terjadi peningkatan kondisi iklim organisasi, maka akan terjadi kenaikan kepuasan kerja dengan tingkat signifikansi $(p=0,000)$.

3) Nilai $\beta X_{3}$ sebesar 0,172 berarti bahwa lingkungan kerja tidak berpengaruh signifikan terhadap kepuasan kerja karyawan LPD Adat 
Qisthio Wibiseno, Dampak Motivasi Kerja, Iklim Organisasi...

Pecatu karena nilai p lebih besar dari $0,05(0,188)$. Hal ini bermakna bahwa variasi kondisi lingkungan kerja tidak berpengaruh terhadap variasi kepuasan kerja karyawan.

4) Nilai $R^{2}$ sebesar 0,484 berarti bahwa variabel motivasi kerja, iklim organisasi, dan lingkungan kerja secara bersama-sama dapat mempengaruhi variabel kepuasan kerja sebesar 48,4\%, sisanya dipengaruhi oleh variabel lain yang tidak diperhitungkan dalam model.

5) Nilai signifikansi $F$ sebesar 0,00 yang lebih kecil dari alpha 5\% atau 0,05 dengan nilai $\mathrm{F}$ hitung sebesar 14,087 berarti bahwa variabel motivasi kerja, iklim organisasi, dan lingkungan kerja secara simultan memiliki pengaruh terhadap variabel kepuasan kerja.

\section{PEMBAHASAN HASIL PENELITIAN}

\section{Pengaruh Motivasi Kerja Terhadap Kepuasan Kerja}

Hipotesis $\left(\mathrm{H}_{1}\right)$ menyatakan bahwa variabel motivasi kerja berpengaruh positif dan signifikan terhadap kepuasan kerja. Berdasarkan hasil uji hipotesis, variabel motivasi kerja tidak berpengaruh signifikan terhadap kepuasan kerja. Hasil yang tidak signifikan tersebut dapat disebabkan oleh beberapa hal, seperti adanya responden dengan persepsi yang berbeda terhadap motivasi kerja atau karena jumlah sampel yang relatif kecil.

Hasil penelitian menunjukkan hasil yang bertolak belakang dengan hipotesis yang berdasar dari hasil penelitian Gîlmeanu (2015), Kartika dan Kaihatu (2012), Singh et al. (2011), Dewi dan Dewi (2015), Zaman et al. (2014), Maurya dan 
Agarwal (2018) Louise dan Botha (2014), Mardiono (2015), Brahmasari dan Suprayetno (2009) serta Stringer et al. (2011) yang dalam penelitian mereka menemukan hubungan positif dan signifikan antara motivasi kerja dengan kepuasan kerja. Akan tetapi hasil penelitian ini sejalan dengan penelitian Dhermawan, et al, (2012) yang menemukan bahwa variabel motivasi kerja tidak berpengaruh signifikan terhadap kepuasan kerja karyawan, sehingga walaupun jika karyawan di LPD Adat Pecatu memiliki motivasi kerja yang baik, hal tersebut tidak akan mempengaruhi kepuasan mereka terhadap pekerjaannya.

Berdasarkan data yang diperoleh, karyawan LPD Adat Pecatu terindikasi memiliki tingkat motivasi kerja yang tinggi, namun tidak berpengaruh terhadap kepuasan kerja. Fenomena ini bisa terjadi karena karyawan yang memiliki motivasi tinggi cenderung mengerahkan seluruh usaha untuk pekerjaannya, sehingga beban yang timbul karena upaya tersebut dapat memicu timbulnya stres kerja dalam jangka waktu panjang. Menurut Robbins dalam Wirda dan Azra (2012), proses motivasi berawal dari keinginan untuk memenuhi kebutuhan yang menimbulkan ketidakpuasan. Rasa tidak puas tersebut kemudian menimbulkan ketegangan dan dorongan untuk melakukan sesuatu untuk memenuhi kebutuhan tersebut. Jika pada tahap ini individu mampu untuk memenuhi kebutuhan tersebut, maka akan timbul rasa puas dan terjadi penurunan ketegangan. Akan tetapi apabila individu tidak mampu memenuhi kebutuhan tersebut, maka akan muncul perasaan ketidakpuasan yang akan mempengaruhi kondisi mental seperti frustrasi atau stres. Bhatti et al. (2011) menyatakan bahwa stres dan kepuasan kerja saling berkaitan. Stres kerja dapat memberikan dampak negatif terhadap kepuasan kerja. Selain karena faktor 
Qisthio Wibiseno, Dampak Motivasi Kerja, Iklim Organisasi...

yang dijelaskan di atas, ketidakpuasan ini juga dapat timbul karena faktor promosi jabatan yang memang sangat jarang ada pada LPD.

Dalam penelitian ini, kondisi motivasi kerja karyawan LPD Adat Pecatu berada pada taraf yang tinggi, namun tidak menguntungkan bagi karyawan itu sendiri karena tingginya motivasi kerja tersebut tidak meemberikan kepuasan terhadap pekerjaannya. Kondisi ini dapat dilihat dalam Gambar 2 pada kuadran II , dimana karyawan memiliki motivasi tinggi dengan kepuasan kerja yang rendah.

Tabel 6.

Hubungan Motivasi dan Kepuasan

\begin{tabular}{|c|c|c|c|c|}
\hline & \multicolumn{4}{|c|}{ Kepuasan } \\
\hline & Tinggi & & & Rendah \\
\hline $\begin{array}{l}\text { Motivasi } \\
\text { Tinggi }\end{array}$ & $\begin{array}{l}\text { I. Nilai } \\
\text { organisasi } \\
\text { karyawan }\end{array}$ & $\begin{array}{l}\text { positif } \\
\text { dan }\end{array}$ & $\begin{array}{l}\text { bagi } \\
\text { bagi }\end{array}$ & $\begin{array}{l}\text { II. Nilai positif bagi } \\
\text { organisasi dan negatif bagi } \\
\text { karyawan }\end{array}$ \\
\hline Rendah & $\begin{array}{l}\text { III. Nila } \\
\text { organisasi } \\
\text { karyawan }\end{array}$ & $\begin{array}{l}\text { negati } \\
\text { positi }\end{array}$ & $\begin{array}{l}\text { bagi } \\
\text { bagi }\end{array}$ & $\begin{array}{lcc}\text { IV. Nilai } & \text { negatif } & \text { bagi } \\
\text { organisasi } & \text { dan } & \text { bagi } \\
\text { karyawan } & & \end{array}$ \\
\hline
\end{tabular}

Sumber: Gomes (1995:179).

Kondisi ini dapat menguntungkan pihak perusahaan karena karyawan akan memiliki performa yang baik karena tingginya motivasi, namun tidak menguntungkan bagi karyawan itu sendiri karena mereka tidak merasa puas akan pekerjaan yang dimilikinya. Ketidakpuasan ini dapat disebabkan oleh sistem promosi jabatan di LPD Adat Pecatu, dimana karyawan tidak mendapatkan kesempatan promosi sesuai dengan harapannya sehingga walaupun karyawan bekerja dengan motivasi yang tinggi, kepuasan mereka terhadap pekerjaannya tidak akan terpenuhi. 


\section{Pengaruh Iklim Organisasi Terhadap Kepuasan Kerja}

Hipotesis $2\left(\mathrm{H}_{2}\right)$ menyatakan bahwa iklim organisasi berpengaruh positif dan signifikan terhadap kepuasan kerja. Berdasarkan hasil uji hipotesis, variabel iklim organisasi menunjukkan hubungan positif dan signifikan terhadap kepuasan kerja karyawan.

Hasil penelitian menunjukkan hasil yang sejalan dengan penelitian Rahimić (2013), Sari (2011), Thakre dan Shroff (2016), Khan et al. (2013), Kumar (2015), serta Yani dan Wijaya (2016) yang juga menemukan hubungan positif dan signifikan antara variabel iklim organisasi dan kepuasan kerja karyawan. Berdasarkan pembahasan tersebut, dapat disimpulkan bahwa semakin baik kondisi iklim organisasi, maka semakin tinggi pula kepuasan kerja karyawan. Karyawan dengan kondisi iklim organisasi baik akan merasa bahwa pekerjaan yang dilakukannya menyenangkan dan berharga. Hal ini dapat terjadi karena karyawan merasa bahwa lingkungan organisasinya yang kondusif dapat memberikan rasa aman sehingga timbul rasa puas terhadap pekerjaan yang dilakukan.

\section{Pengaruh Lingkungan Kerja Terhadap Kepuasan Kerja}

Hipotesis $3\left(\mathrm{H}_{3}\right)$ menyatakan bahwa lingkungan kerja berpengaruh positif terhadap kepuasan kerja. Berdasarkan hasil uji hipotesis, variabel motivasi kerja tidak berpengaruh signifikan terhadap kepuasan kerja karyawan LPD Adat Pecatu. Hasil yang tidak signifikan tersebut dapat disebabkan oleh beberapa responden yang bekerja di luar kantor. Dalam penelitian ini, indikator yang digunakan hanya mengacu pada kondisi lingkungan kerja di kantor LPD Adat Pecatu saja sehingga 
Qisthio Wibiseno, Dampak Motivasi Kerja, Iklim Organisasi...

responden yang bekerja di luar kantor mungkin tidak bisa memberikan jawaban yang akurat terhadap kuesioner yang disebarkan.

Hasil penelitian menunjukkan hasil yang bertolakbelakang dengan penelitian terdahulu oleh Sardzoska \& Tang (2012), Annakis et al. (2011), Ashraf et al. (2013), Raziq \& Maulabakhsh (2015), Aruan \& Fakhri (2017) dan Wibowo (2014), dan Al-Hamdan et al. (2017) yang menyatakan bahwa variabel lingkungan kerja berpengaruh positif dan signifikan terhadap kepuasan kerja karyawan Akan tetapi penelitian ini menemukan hasil yang sejalan dengan penelitian Dhermawan et al. (2012) yang menemukan bahwa variabel lingkungan kerja tidak memiliki pengaruh signifikan terhadap kepuasan kerja karyawan. Hal ini berarti bahwa jika karyawan LPD Adat Pecatu memiliki lingkungan kerja yang baik, hal tersebut tidak akan mempengaruhi kepuasan mereka terhadap pekerjaannya secara signifikan.

Fenomena tersebut dapat terjadi karena sebagian besar karyawan LPD Adat Pecatu lebih banyak menghabiskan waktu bekerja di lapangan, sehingga walaupun kondisi ruang kerja mereka tidak nyaman, mereka akan tetap bisa bekerja seperti biasanya karena pada dasarnya mereka hanya menghabiskan sebagian kecil waktu mereka untuk bekerja di ruang kerja mereka. Hal tersebut juga dapat menyebabkan tingginya tingkat adaptasi karyawan terhadap lingkungan kerja yang berubah-ubah, sehingga mereka dapat bekerja dengan optimal walaupun dengan kondisi lingkungan kerja yang dinamis.

\section{Dukungan Teori Dua Faktor Terhadap Hasil Penelitian}

Teori dua faktor yang terdiri dari Hygiene factor dan motivational factor dalam penelitian ini tidak sepenuhnya terdukung dalam penelitian ini karena 
variabel motivasi kerja dan variabel lingkungan kerja yang didasari teori dua faktor ini terindikasi tidak memiliki pengaruh yang signifikan terhadap kepuasan kerja karyawan LPD Adat Pecatu.

\section{SIMPULAN DAN SARAN}

Berdasarkan hasil analisis data penelitian yang sudah dibahas pada bab sebelumnya, maka simpulan dari penelitian ini adalah sebagai berikut.

1) Motivasi kerja tidak memiliki pengaruh terhadap kepuasan kerja karyawan LPD Adat Pecatu. Hal ini bermakna bahwa motivasi kerja tidak berkontribusi terhadap variasi kepuasan kerja.

2) Iklim organisasi memiliki pengaruh positif dan signifikan terhadap kepuasan kerja karyawan LPD Adat Pecatu. Hal ini berarti semakin baik kondisi iklim organisasi di LPD Adat Pecatu, maka semakin baik pula kepuasan kerja karyawan.

3) Lingkungan kerja tidak memiliki pengaruh terhadap kepuasan kerja karyawan LPD Adat Pecatu. Hal ini berarti bahwa baik-buruknya kondisi lingkungan kerja tidak akan mempengaruhi kepuasan kerja karyawan LPD Adat Pecatu.

Berdasarkan simpulan yang telah diuraikan di atas, berikut adalah saran yang diusulkan oleh peneliti.

1) Pihak pengurus dan karyawan LPD Adat Pecatu diharapkan lebih dapat menghargai pendapat baik antara sesama karyawan dan antara karyawan dengan pimpinan atau pengurus karena beberapa karyawan merasa bahwa ada keterbatasan untuk menyampaikan pendapat. 
Qisthio Wibiseno, Dampak Motivasi Kerja, Iklim Organisasi...

2) Pihak pengurus LPD Adat Pecatu diharapkan dapat lebih mempertimbangkan sistem pengembangan promosi jabatan karyawan demi meningkatkan kepuasan kerja karyawan di LPD Adat Pecatu.

\section{REFERENSI}

Afriani, F. 2013. Pengaruh Iklim Organisasi terhadap Kepuasan Kerja Pegawai pada Kantor Kecamatan Kepenuhan Hulu. Jurnal Mahasiswa Prodi S1 Manajemen, 1(1): hal.1-3.

Ahyari, A. 2005. Manajemen Produksi Perencanaan Sistem Produksi. Buku 2. Yogyakarta: BPFE.

Al-Hamdan, Z., Manojlovich, M., \& Tanima, B. 2017. Jordanian Nursing Work Environments, Intent to Stay, and Job Satisfaction. Journal of Nursing Scholarship, 49(1): pp. 103-110.

Annakis, J., Lobo, A., \& Pillay, S. 2011. Exploring Monitoring, Work Environment and Flexibility as Predictors of Job Satisfaction within Australian Call Centres. International Journal of Business and Management, 6(8): pp. 7593.

Aruan, Q. S., \& Fakhri, M. 2017. Pengaruh Lingkungan Kerja Terhadap Kepuasan Kerja Karyawan Lapangan Departemen Grasberg. Modus Journals, 27(2): hal.141-162.

Asif, F. 2011. Estimating the Impact of Denison's (1996), 'What is the Difference Between Organizational Culture and Organizational Climate? A Native's Point of View on A Decade of Paradigm Wars. Journal of Business Research, 64(5): pp.454-459.

Ashraf, M. S., Bashir, M., Bilal, M. Y., Ijaz, K., \& Usman, M. 2013. The Impact of Working Environment on Organization Performance: A Mediating Role Employee's Job Satisfaction. Global Management Journal For Academic \& Corporate Studies, 3(1): pp.131-150.

Aziri, B. 2011. Job Satisfaction: A Literature Review. Management Research \& Practice, 3(4): pp.77-86.

Bakhtiar, D. 2012. Pengaruh Motivasi dan Lingkungan Kerja terhadap Kinerja Karyawan. Management Analysis Journal. 1(1): hal.1-6. 
Bhatti, N., Jiskani. M., Pathan, M. A., \& Magsi, M. R. 2011. Empirical Analysis of Job Stress on Job Satisfaction Among University Teachers in Pakistan. International Business Research, 4(3): pp. 264-270.

Brahmasari, I. A., \& Suprayetno, A. 2009. Pengaruh Motivasi Kerja, Kepemimpinan dan Budaya Organisasi Terhadap Kepuasan Kerja Karyawan Serta Dampaknya Pada Kinerja Perusahaan (Studi Kasus Pada PT. Pei Hai International Wiratama Indonesia). Jurnal Manajemen dan Kewirausahaan, 10(2): hal. 124-135.

Brown, M., Hyatt, D., \& Benson, J. 2010. Consequences of the Performance Appraisal Experience. Personnel Review, 39: pp.375-396.

Dewi, P. E. P \& Dewi, I G. A. M. 2015. Pengaruh Self-Efficacy dan Motivasi Kerja Pada Kepuasan Kerja Karyawan Happy Bali Tour \& Travel Denpasar. Matrik : Jurnal Manajemen, Strategi Bisnis dan Kewirausahaan, 9(1): hal.15-25

Dhermawan, A. A. N. B., Sudibya, I. G. A., \& Utama, I. W. M. 2012. Pengaruh Motivasi, Lingkungan Kerja, Kompetensi, dan Kompensasi Terhadap Kepuasan Kerja dan Kinerja Pegawai di Lingkungan Kantor Dinas Pekerjaan Umum Provinsi Bali. Matrik: Jurnal Manajemen, Strategi Bisnis dan Kewirausahaan, 6(2): hal.173-184

Gîlmeanu, M. R. 2015. Theoretical Considerations on Motivation at The Work Place, Job Satisfaction and Individual Performance. Valahian Journal of Economic Studies, 6(3): pp.69-80.

Gomes, F. C. 1995. Manajemen Sumber Daya Manusia. Yogyakarta: Penerbit ANDI.

Hoboubi, N., Choobineh, A., Kamari G., F., Keshavarzi, S., \& Akbar H. A. 2016. The Impact of Job Stress and Job Satisfaction on Workforce Productivity in an Iranian Petrochemical Industry. Safety and Health at Work, 8(1): pp.6771 .

Kartika, E. W., \& Kaihatu, T. S. 2010. Analisis pengaruh Motivasi kerja terhadap kepuasan kerja (Studi Kasus Pada Karyawan Restoran di Pakuwon Food Festival Surabaya). Jurnal Manajemen dan Kewirausahaan, 12(1): hal.100-112.

Khan, A., Ramzan, M., \& Butt, M. S. 2013. Is Job Satisfaction of Islamic Banks Operational Staff Determined Through Organizational Climate, Occupational Stress, Age and Gender. Journal of Business Studies Quarterly, 4(3): pp. 13-26. 
Kumar, R. 2015. Perceptual Differences About Organizational Climate And Job Satisfaction Between Teaching and Non Teaching Staff. American Journal of Management, 15(3): pp.87-112.

Kustianto, F. \& Iskhak, A. A. 2015. Pengaruh Iklim Orgnisasi Terhadap Komitmen Karyawan Dengan Kepuasan Kerja Sebagai Variabel Intervening Pada PT. Garam (Persero). Jurnal Ilmu Manajemen Magistra, 1(1): hal. 42-55.

Louise, V. S., \& Botha, J. 2014. Analysing Relationship Between Employee Job Satisfaction and Motivation. Journal of Business and Retail Management Research, 09(1): pp. 98-109.

Luthans, F. 2006. Organizational Behavior, edisi 11. New York: McGraw-Hill, Inc.

Mardiono, D. 2015. Pengaruh Motivasi dan Disiplin Kerja Terhadap Kepuasan Kerja Karyawan. Jurnal Ilmu \& Riset Manajemen, 3(3): hal.1-19.

Maurya, M. K., \& Agarwal, M. 2018. Relationship Between Motivation to Lead, Mental Health Status, and Job Satisfaction of Male and Female Civil Police Constables. Journal of Police and Criminal Psychology, 33(1): pp. 9-20.

Newsham, G. 2009. Linking Indoor Environment Conditions to Job Satisfaction. Building Research \& Information. 37(2): pp. 129-147.

Paramita, W., Prayuda, W. H., \& Handaru, A. W. 2013. Pengaruh Lingkungan Kerja Dan Budaya Organisasi Terhadap Kepuasan Kerja Karyawan Pada Bank BTN (PERSERO) Cabang Bekasi. JRMSI-Jurnal Riset Manajemen Sains Indonesia, 4(2: hal. 257-275.

Rahimić, Z. 2013. Influence of Organizational Climate on Job Satisfaction in Bosnia and Herzegovina Companies. International Business Research, 6(3): pp. 129-139.

Raziq, A., \& Maulabakhsh, R. 2015. Impact of Working Environment on Job Satisfaction. Procedia Economics and Finance, 23: pp. 717-725.

Robbins, S. P. 2002. Perilaku Organisasi. Edisi kelima. Jakarta: Penerbit Erlangga.

Sardzoska, E. G., \& Tang, T. L. 2012. Work-Related Behavioral Intentions in Macedonia: Coping Strategies, Work Environment, Love of Money, Job Satisfaction, and Demographic Variables. Journal of Business Ethics, 108(3): pp. 373-391.

Sari, E. 2011. Pengaruh Kompensasi dan Iklim Organisasi Terhadap Kepuasan Kerja. BISNIS \& BIROKRASI: Jurnal Ilmu Administrasi dan Organisasi, 16(1): hal.18-24 
Setiawan, K. C. 2015. Pengaruh Iklim Organisasi Terhadap Kinerja Karyawan Level Pelaksana di Divisi Operasi PT. Pusri Palembang. PSIKIS-Jurnal Psikologi Islami, 1(1): hal. 23-32.

Singh, R. R., Chauhan A., Agrawal, S., Kapoor, S. 2011. Impact of Organisational Climate on Job Satisfaction - A Comparative Study. IJCSMS International Journal of Computer Science and Management Studies, 11(02): pp. 9-18.

Stringer, C., Didham, J., \& Theivananthampillai, P. 2011. Motivation, pay satisfaction, and job satisfaction of front-line employees. Qualitative Research in Accounting and Management, 8(2): pp. 161-179.

Subagyo, A. 2014. Pengaruh Lingkungan Kerja dan Self Efficacy Terhadap Komitmen Organisasional Dosen Politeknik Negeri Semarang. Orbith. 10(1): hal.74-81.

Surachim, A. 2008. Pengaruh Iklim Organisasi terhadap Kepuasan Kerja Karyawan Pada Divisi Pharmaserve di PT Combiphar Jakarta. Strategic, 7(13): hal. 58-64.

Susanty, E. 2012. Pengaruh iklim organisasi terhadap kepuasan kerja dan komitmen karyawan pada universitas terbuka. Jurnal Organisasi dan Manajemen, 8(2): hal.121-134.

Thakre, N. \& Shroff, N. 2016. Organizational climate, organizational role stress and job satisfaction among employees. Journal of Psychosocial Research, 11(2): pp. 469-478.

Wibowo, M. 2014. Pengaruh Lingkungan Kerja Terhadap Kepuasan Kerja Karyawan (Studi pada Karyawan PT. Telekomunikasi Indonesia Tbk. Kandatel Malang). Jurnal Administrasi Bisnis, 16(1): hal. 1-9.

Wirda, F. \& Azra, T. 2012. Pengaruh Gaya Kepemimpinan Situsional dan Motivasi Kerja Terhadap Kepuasan Kerja Karyawan Politeknik Negeri Padang. Polibisnis, 4(1): hal. 24-33.

Yani, T. I., \& Wijaya, E. Y. 2016. Pengaruh Iklim Organisasi, Perilaku Kerja dan Fungsi Pengawasan terhadap Kepuasan Kerja Karyawan pada PT. Bank Mandiri Cabang Pekanbaru Sudirman Atas di Kota Pekanbaru. Jurnal Online Mahasiswa (JOM) Bidang Ilmu Ekonomi, 4(1): hal.402-413.

Zaman, F. B., Noor, M., \& Khanam, B. 2014. Relationship of Work Motivation and Organisational Commitment with Job Satisfaction of Female Police Constables. Journal of Organisation and Human Behaviour, 3(4): pp. 1-9. 